\title{
Determination of ultra-trace amounts of silver in water by differential pulse anodic stripping voltammetry using a new modified carbon paste electrode
}

\author{
Hafida El-Mai ${ }^{\text {a }}$, Estrella Espada-Bellido ${ }^{\text {a,* }}$, Mostafa Stitou ${ }^{\text {b }}$, Manuel García-Vargas a , \\ Maria Dolores Galindo-Riaño ${ }^{a}$ \\ ${ }^{a}$ Department of Analytical Chemistry, Institute of Biomolecules (INBIO), Faculty of Sciences, CEI-MAR, University of Cadiz, Campus Rio San Pedro, Puerto Real \\ 11510, Cadiz, Spain \\ ${ }^{\mathrm{b}}$ Department of Chemistry, Faculty of Sciences, University of Abdelmalek Essaadi, B.P. 2121 M'hannech II, Tetouan 93002, Morocco
}

\section{A R T I C L E I N F O}

\section{Article history:}

Received 25 August 2015

Received in revised form

3 January 2016

Accepted 8 January 2016

Available online 9 January 2016

\section{Keywords:}

Silver

Speciation

Differential pulse anodic stripping voltammetry

Modified carbon paste electrode

Mercury-free electrode

Water

\begin{abstract}
A B S T R A C T
A highly sensitive and selective new procedure for the determination of silver in aqueous media was developed using a modified carbon paste electrode (MCPE) by differential pulse anodic stripping voltammetry (DPASV). The modified electrode was based on the incorporation of 2-hydroxybenzaldehyde benzoylhydrazone $(2-\mathrm{HBBH})$ in the carbon paste electrode. Silver ions were preconcentrated on the modified electrode at open-circuit by complexation with the ligand and reduced to zero valent at a potential of $0 \mathrm{~V}$, and followed by the reoxidation of adsorbed ions onto the electrode by scanning the potential in a positive direction. The oxidation peak of $\mathrm{Ag}(\mathrm{I})$ was observed at $0.2 \mathrm{~V}$ (versus $\mathrm{Ag} / \mathrm{AgCl}$ ). $\mathrm{The}$ analysis of $\mathrm{Ag}(\mathrm{I})$ was carried out in a cell containing the sample solution $(20 \mathrm{~mL})$ buffered by $0.1 \mathrm{~mol} \mathrm{~L}^{-1}$ $\mathrm{K}_{2} \mathrm{HPO}_{4} / \mathrm{NaOH}$ at $\mathrm{pH} 5.5$ in aqueous solution and nitric acid $(\mathrm{pH} 1)$ in real water samples. The optimum conditions for the analysis of silver include a reduction potential of $0 \mathrm{~V}$ and a pulse amplitude of $100 \mathrm{mV}$, among others. The optimum carbon paste composition was found to be $14.1 \%(\mathrm{w} / \mathrm{w}) 2-\mathrm{HBBH}, 56.2 \%(\mathrm{w} /$ w) graphite powder and $29.7 \%(\mathrm{w} / \mathrm{w})$ paraffin oil. Differential pulse anodic stripping voltammetric response was used as the analytical signal. Under the selected conditions, the voltammetric signal was proportional to the $\mathrm{Ag}(\mathrm{I})$ concentration in the range of $0.001-100 \mu \mathrm{g} \mathrm{L}^{-1}$ with favorable limits of detection and quantification of $1.1 \mathrm{ng} \mathrm{L}^{-1}$ and $3.7 \mathrm{ng} \mathrm{L}^{-1}$ after 3 min of accumulation time, respectively. By increasing the accumulation time to $10 \mathrm{~min}$, detection and quantification limits can be further improved up to $0.1 \mathrm{ng} \mathrm{L}^{-1}$ and $0.34 \mathrm{ng} \mathrm{L}^{-1}$, respectively. In addition, the results showed a highly reproducible procedure showing a relative standard deviation of $1.5 \%$ for 12 replicate measurements. Many coexisting metal ions were investigated and very few interferences were found on the determination of $\operatorname{Ag}(\mathrm{I})$. The proposed method was validated using certified reference estuarine waters (SLEW-3) with a relative error of $-1.3 \%$ and applied to the determination of silver ions in three river water samples collected from Guadalquivir river (relative errors of $+3.4 \%,+1.5 \%$ and $-0.7 \%$ ). Moreover, the method was successfully applied to the speciation analysis of total silver, free silver ions and silver nanoparticles in aqueous solutions. The results were in good agreement with those obtained by inductively coupled plasma mass spectrometry (ICP-MS).
\end{abstract}

(c) 2016 Elsevier B.V. All rights reserved.

\section{Introduction}

Silver is a contaminant of environmental concern in marine and estuarine waters, but little has been published exclusively about this element [1,2]. The easy bioaccumulation and high toxicity to aquatic organisms of its ionic form are only exceeded

\footnotetext{
* Corresponding author.

E-mail address: estrella.espada@uca.es (E. Espada-Bellido).
}

by mercury $[3,4]$. The metal occurs naturally in ores such as argentite $\left(\mathrm{Ag}_{2} \mathrm{~S}\right)$ and horn silver $(\mathrm{AgCl})$ [5]. Nevertheless, the main sources of silver for the marine environment derive from anthropogenic inputs such as medicine, pharmacy, photography, electronic equipments, and the production of jewelry, coins, batteries, dental fillings, among others [1,6,7]. In a relatively short time, the increasing development of nanotechnology has evidently led to the emission of many different nanomaterials into the aquatic environment. Thus, silver nanoparticles (AgNPs) 
can be encountered in numerous consumer products due to their excellent anti-microbial properties such as textiles, personal care products, paints, food storage containers, laundry additives, medical devices, electronic and water purification systems. On account of these uses and their possibly toxic effects in human and aquatic organisms, the determination of silver nanoparticles in water samples can be also considered of great interest in the aquatic field [8-12]. Due to their bactericidal properties, silver salts and silver nanoparticles are used in disinfection of drinking water [13-15]. Therefore, silver can be used as a tracer for monitoring domestic and industrial inputs [16] being of great interest the analysis of this ion in water samples. Regarding the maximum contaminant level for total silver in drinking water, the US Environmental Protection Agency (EPA) fixed it as $0.1 \mathrm{mg} \mathrm{L}^{-1}$ [17]. However, it is also reported that the concentration of silver in water higher than $0.17 \mu \mathrm{g} \mathrm{L}^{-1}$ is toxic to fish and microorganisms [18]. Thus, the low concentrations of silver in waters as well as the complexity of the sample matrix, make the determination of silver extremely challenging. Stripping voltammetric techniques have been employed in the literature for the analysis of metals in water. Anodic stripping voltammetry has shown the advantages of speed of analysis, good selectivity and sensitivity, excellent accuracy and precision, among others. However, several problems occur for silver determination using mercury electrode due to the highly positive reduction potential of this ion. This difficulty can be overcome using chemically modified electrodes apart from the obvious necessity of reducing the use of mercury. Among all the modified electrodes, the application of modified carbon paste electrodes (MCPE) has reached considerable attention for stripping voltammetry in recent years as a green alternative due to its simplicity, versatility, low cost and ease of construction without the requirement of rigorous chemical methods for the modification of the paste [19-21]. Besides, the low residual currents, the wide potential range and easy renewability of the surface make these mercury-free electrodes an excellent alternative for metal analysis being one of the most popular electrode materials [20,22-24]. MCPE are widely used in potentiometry [18,25-28] for the determination of $\mathrm{Ag}(\mathrm{I})$. Nevertheless, these types of electrodes have been rarely developed for the determination of $\mathrm{Ag}(\mathrm{I})$ in the field of stripping voltammetry. The classical carbon paste electrode without modification was proposed for the determination of $\mathrm{Ag}(\mathrm{I})$ and $\mathrm{Cu}(\mathrm{I})$ ions in 1997 [29]. However, the lack of specificity vs. the chemically modified carbon paste electrodes was evident. A few complexing agents, such as Alizarin violet [30], 3-amino-2-mercapto quinazolin-4 (3H)-one [31], Tu-SBA-15 [32], have been proposed in the last decade for the modification of the carbon paste to determine such ions. In the present work, 2-hydroxybenzaldehyde benzoylhydrazone (2-HBBH) was chosen as the complexing ligand to modify the carbon paste electrode and determine $\mathrm{Ag}(\mathrm{I})$ in water samples. This aroylhydrazone is considered an important chelating agent because of its donor properties in coordinating a large variety of metals $[33,34]$ and the ability to behave as polydentate ligand but until now it has not been used as modifier of carbon paste electrode for the determination of silver in water samples. On the other hand, speciation of silver in natural waters is also necessary due to the different toxicity of each of its forms. In this paper, a highly sensitive and selective new non-mercury electrode for the determination of silver ions and silver nanoparticles in aqueous media is presented using a MCPE by the incorporation of the Schiff base $2-\mathrm{HBBH}$ in the carbon paste mixture.

\section{Experimental}

\subsection{Instrumentation and apparatus}

Voltammograms were recorded with a Metrohm Computrace Voltammetric Analyzer (model 746 VA Trace Analyzer with 747 VA Stand) instrument (Metrohm, Switzerland). A one-compartment electrochemical cell with a three-electrode system consisting of a $\mathrm{Ag} / \mathrm{AgCl}$ reference electrode $\left(3 \mathrm{~mol} \mathrm{~L}^{-1} \mathrm{KCl}\right)$, a platinum wire as auxiliary electrode, and a MCPE as working electrode. The stand was controlled by PC software VA Computrace 2.0 installed in a personal computer using a 5326 VA Computrace Interface (Metrohm, Switzerland). A V-650 spectrophotometer (JASCO, USA) was used for recording UV-vis spectroscopic measurements with $1 \mathrm{~cm}$ quartz glass cells $(1 \mathrm{~cm} \times 1 \mathrm{~cm} \times 4.5 \mathrm{~cm})$, for determining the stoichiometry of the Ag-2-HBBH complex formed. Organic matter was removed for real water samples by UV irradiation with a Metrohm model 705 UV Digester (Metrohm, Switzerland) in quartz tubes. A model 2001 pH-meter equipped with 52-02 combined glass- $\mathrm{Ag} / \mathrm{AgCl}$ electrode (Crison, Spain) was used for adjusting $\mathrm{pH}$ values. Water was purified by reverse osmosis with an Elix 3 (Milli-RO) system followed by ion exchange with an $18 \mathrm{M} \Omega \mathrm{cm}$ deionised Milli- $\mathrm{Q}^{50}$ system (Millipore, USA). For validation studies, a Thermo X7 Series Inductively Coupled Plasma Mass Spectrometer (ICP-MS) was employed (Thermo Elemental, UK).

\subsection{Reagents}

All reagents were of analytical reagent grade and all solutions were prepared using Milli-Q deionised water. Graphite powder (Natural, High Purity, - 200 mesh, 99.9999\% (metals basis), Alfa Aesar) and paraffin oil ((USP, BP, Ph, Eur.) PRS-CODEX, Panreac) were used directly without further purification. Working standard solution of $10 \mathrm{mg} \mathrm{L}^{-1} \mathrm{Ag}(\mathrm{I})$ was prepared by dilution of $\mathrm{Ag}$ standard solution of $1000 \mathrm{mg} \mathrm{L}^{-1}$ (Merck, Darmstadt, Germany) in $0.03 \mathrm{~mol} \mathrm{~L}^{-1} \mathrm{HNO}_{3}$.

Different buffer solutions were prepared: $1 \mathrm{~mol} \mathrm{~L}^{-1}$ HEPES ( $\mathrm{pH}$ 7 to 8 ) from $\mathrm{N}$-2-hydroxyethylpiperazine- $\mathrm{N}^{\prime}$-2-ethane sulfonic acid (Sigma-Aldrich, Steinheim, Germany) and suprapur ammonia (Merck, Darmstadt, Germany); $1.5 \mathrm{~mol} \mathrm{~L}^{-1}$ Britton-Robinson buffer solutions ( $\mathrm{pH} 2$ to 10 ), prepared according to previously reported method [35], using o-boric acid, o-phosphoric acid, acetic acid and sodium hydroxide (Merck, Darmstadt, Germany), with a constant ionic strength obtained by adding $\mathrm{KCl}$ (Merck, Darmstadt, Germany); $1 \mathrm{~mol} \mathrm{~L}^{-1}$ ammonium chloride/ammonia ( $\mathrm{pH} 8$ and 9) (Merck, Darmstadt, Germany); $4 \mathrm{~mol} \mathrm{~L}^{-1}$ acetic acid/sodium acetate ( $\mathrm{pH} 4$ to 5.5) (Merck, Darmstadt, Germany); Hydrion Phosphate Buffer Chemvelopes purchased from Sigma-Aldrich at different $\mathrm{pH}$ values ( $\mathrm{pH} 2$ to 10 ) by adding to $500 \mathrm{~mL}$ of distilled deionised water. For the optimum conditions, phosphate buffer was prepared using $1 \mathrm{~mol} \mathrm{~L}^{-1}$ potassium dihydrogen orthophosphate $\left(\mathrm{KH}_{2} \mathrm{PO}_{4}\right)$ (Sigma-Aldrich, Steinheim, Germany) and $1 \mathrm{~mol} \mathrm{~L}^{-1} \mathrm{NaOH}$ (Merck, Darmstadt, Germany). $\mathrm{HNO}_{3}$ of Suprapur grade (Merck) was also employed to adjust $\mathrm{pH}$ for optimum conditions.

High quality nitrogen was used for deaeration of solution prior to any electrochemical measurements. The 2-hydroxybenzaldehyde benzoylhydrazone (2-HBBH) was synthesized as previously reported by Espada et al. [36] and then recrystallized three times in 1:1 ethanol/water. The structure is shown in Fig. 1.

The total dissolved silver was ascertained in the estuarine water reference material (SLEW-3) from the National Research Council of Canada. The proposed method was also applied to real water samples from Guadalquivir river (southwest of Spain). Samples were filtered through $0.45 \mu \mathrm{m}$ pore size filters, acidified 


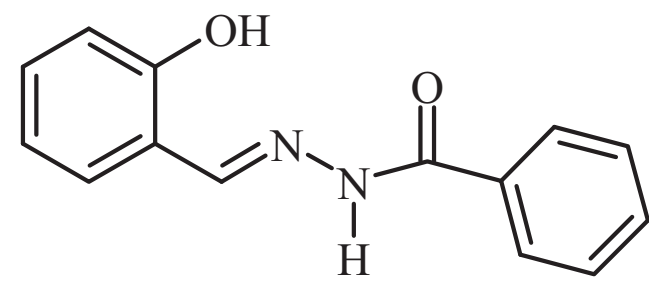

Fig. 1. 2-hydroxybenzaldehyde benzoylhydrazone (2-HBBH).

with $\mathrm{HNO}_{3}$ of Suprapur grade (Merck) up to $\mathrm{pH}<2$ and stored under $4{ }^{\circ} \mathrm{C}$ until application of the method. Before analysis, organic matter of samples was destroyed by adding of $0.02 \mathrm{~mol} \mathrm{~L}^{-1}$ hydrogen peroxide of Suprapur grade (Merck) and UV digestion during $2 \mathrm{~h}$.

For the analysis of silver nanoparticles, two aqueous solutions were studied: a dispersion of silver nanoparticles containing sodium citrate as stabilizer (Sigma-Aldrich, Steinheim, Germany) and silver nanoparticles prepared in the laboratory by dissolving a specific amount of silver powder (Sigma-Aldrich, Steinheim, Germany). Both aqueous solutions consisted on colloidal silver nanoparticles of $20 \mathrm{~nm}$ particle size. For speciation studies, samples were filtered through Nucleopore Track-Etch Membrane of $15 \mathrm{~nm}$ pore size filters.

\subsection{Preparation of the modified carbon paste electrode}

Teflon cylindrical tube ( $5 \mathrm{~cm}$ length) with a hole at one end ( $2.9 \mathrm{~mm}$ inner diameter and $1.25 \mathrm{~mm}$ of deep cavity) for the carbon paste filling served as the electrode body. Unmodified electrode was prepared by thoroughly hand-mixing $0.1 \mathrm{~g}$ of high purity graphite powder with $0.042 \mathrm{~g}$ of paraffin oil in a mortar and pestle until a homogeneous carbon paste was obtained. The MCPE was prepared in a similar way except that the graphite powder $(0.08 \mathrm{~g})$ was first mixed with the desired weight of $2-\mathrm{HBBH}$ $(0.02 \mathrm{~g})$ in a mortar followed by the addition of $0.042 \mathrm{~g}$ of paraffin oil to the carbon paste mixture and mixed until obtaining a uniform paste. Subsequently, the paste was packed firmly into the electrode cavity and smooth surfaces were obtained by applying manual pressure to the tip while polishing on a sandpaper. After each measurement, the electrode surface was renewed by pushing approximately $0.5 \mathrm{~mm}$ of carbon paste out of the tube with a spatula, and smoothing it again mechanically to get a fresh surface.

\subsection{Electrochemical reaction mechanism}

The proposed mechanism for the determination of silver using the 2-HBBH modified carbon paste electrode is attributed to the following three steps after a purging time with nitrogen: accumulation, reduction and stripping step. During the accumulation step, under stirring conditions and at open-circuit, $\mathrm{Ag}^{+}$is adsorbed on the electrode surface and is complexed by 2-HBBH. Subsequently, $\mathrm{Ag}^{+}-2-\mathrm{HBBH}$ complex is broken due to the reduction of $\mathrm{Ag}^{+}$to $\mathrm{Ag}^{0}$ at $0 \mathrm{~V}$ during the reduction step. Immediately, a potential scan in the anodic direction is carried out to measure the amount of reduced $\mathrm{Ag}^{0}$ from its oxidation current to $\mathrm{Ag}^{+}$stripped off producing a peak at $0.2 \mathrm{~V}$. Differential pulse voltammetry (DPV) was employed for the quantitative determination of $\mathrm{Ag}(\mathrm{I})$ due to the high sensitivity and good shape achieved [37,38].

\subsection{General procedure to determine silver}

Cyclic voltammetry was employed to check for normal electrochemical behavior of the novel working electrode. The MCPE was immersed in a stirred cell containing the appropriate concentration of $\mathrm{Ag}(\mathrm{I})$ in $20 \mathrm{~mL}$ of $0.1 \mathrm{~mol} \mathrm{~L}^{-1}$ Britton-Robinson buffer solution ( $\mathrm{pH} 6$ ) after purging with nitrogen for $5 \mathrm{~min}$. Cyclic voltammograms (CVs) were run in anodic direction from -1.5 to $1.5 \mathrm{~V}$ vs. $\mathrm{Ag} / \mathrm{AgCl}$ with a scan rate of $100 \mathrm{mV} \mathrm{s}^{-1}$ after an acumulation time of $5 \mathrm{~min}$ at open-circuit and back at the same scan rate.

For differential pulse anodic stripping voltammetric measurements, the analysis of $\mathrm{Ag}(\mathrm{I})$ was carried out in a cell containing the sample solution $(20 \mathrm{~mL})$ and $0.1 \mathrm{~mol} \mathrm{~L}^{-1} \mathrm{~K}_{2} \mathrm{HPO}_{4} / \mathrm{NaOH}$ buffer at slightly acid $\mathrm{pH}$ ( $\mathrm{pH} 5.5)$ for aqueous solutions and nitric acid $(\mathrm{pH}$ 1) for real water samples, respectively. The buffered condition is employed without the presence of chloride ions in the solution, whilst acid $\mathrm{pH}(\mathrm{pH} 1)$ is used in the presence of chloride ions because of the possible precipitation of $\mathrm{Ag}(\mathrm{I})$ at slightly acid $\mathrm{pH}$. The solution was deoxygenated by $\mathrm{N}_{2}$-purging ( $3 \mathrm{~min}$ ) previously the following steps. (1) Accumulation step of $\mathrm{Ag}(\mathrm{I})$ was done at open-circuit for $3 \mathrm{~min}$ in a stirred solution. After that, the stirring was stopped and the solution was left settle for an equilibration period of $5 \mathrm{~s}$. (2) Reduction step was developed at a reduction potential of $0 \mathrm{~V}$ (versus $\mathrm{Ag} / \mathrm{AgCl}$ reference electrode) for $3 \mathrm{~min}$ in a stirred solution. (3) Then, stripping step was carried out with a scan of the potential in a differential pulse mode of operation toward a positive direction from -0.4 to $0.7 \mathrm{~V}$ at a scan rate of $100 \mathrm{mV} \mathrm{s}^{-1}$ to obtain the corresponding voltammogram. Table 1 summarises the operating conditions optimized for the differential pulse voltammetric measurements. All electrochemical experiments were conducted at room temperature at about $298 \mathrm{~K}$. A renewed carbon paste surface was used for each measurement.

\section{Results and discussions}

Preliminary measurements by cyclic voltammetry (CV) showed the $\mathrm{Ag}(\mathrm{I})-2-\mathrm{HBBH}$ complex formation at $\mathrm{pH}$ 6. Fig. 2a shows cyclic voltammograms for the following conditions: (1) CPE without 2-HBBH and $2 \mathrm{mg} \mathrm{L}^{-1} \mathrm{Ag}(\mathrm{I})$; (2) MCPE with 2-HBBH without $\mathrm{Ag}(\mathrm{I})$; and (3) MCPE with 2-HBBH and $2 \mathrm{mg} \mathrm{L}^{-1} \mathrm{Ag}(\mathrm{I})$. The oxidation peak of $\mathrm{Ag}(\mathrm{I})$ was observed at $0.1 \mathrm{~V}$ (versus $\mathrm{Ag} / \mathrm{AgCl}$ ). Both (1) and (2) conditions did not show peak current at this potential. On the other hand, preliminary studies by differential pulse anodic stripping voltammetry (DPASV) of $100 \mu \mathrm{g} \mathrm{L}^{-1} \mathrm{Ag}(\mathrm{I})$ using a MCPE with 2-HBBH were carried out. The oxidation peak of $\mathrm{Ag}(\mathrm{I})$ was observed at $0.2 \mathrm{~V}$ (versus $\mathrm{Ag} / \mathrm{AgCl}$ ) with a higher sensitivity (Fig. 2b).

2-HBBH was optically characterized by ultraviolet-visible (UVvis) absorption spectroscopy showing two important transitions at $288 \mathrm{~nm}$ and $324 \mathrm{~nm}$. When silver solution was added, a new high

Table 1

Operating conditions optimized for the differential pulse voltammetric measurements of $\mathrm{Ag}(\mathrm{I})$ using a MCPE.

\begin{tabular}{ll}
\hline Parameter & Value \\
\hline pH and buffer & $\begin{array}{l}\text { Aqueous solution: } 0.1 \mathrm{~mol} \mathrm{~L}^{-1} \mathrm{~K}_{2} \mathrm{HPO}_{4} / \mathrm{NaOH}(\mathrm{pH} 5.5) \\
\text { composition }\end{array}$ \\
$\begin{array}{l}\text { Real water samples: } \mathrm{HNO}_{3}(\mathrm{pH} 1) \\
\text { Purge time }\end{array}$ & $180 \mathrm{~s}$ \\
Accumulation time & $180 \mathrm{~s}(600 \mathrm{~s}$ maximum $)$ \\
Reduction potential & $0 \mathrm{~V}$ \\
Reduction time & $180 \mathrm{~s}(420 \mathrm{~s}$ maximum) \\
Equilibration time & $5 \mathrm{~s}$ \\
Pulse amplitude & $100 \mathrm{mV}$ \\
Potential step & $10 \mathrm{mV}$ \\
Time interval for po- & $0.1 \mathrm{~s}$ \\
$\quad$ tential step & \\
Pulse time & $40 \mathrm{~ms}$ \\
Stirring speed & $2000 \mathrm{rpm}$ \\
Stirring during reduc- & Yes \\
$\quad$ tion step & -0.4 to $0.7 \mathrm{~V}$ \\
Potential scan &
\end{tabular}



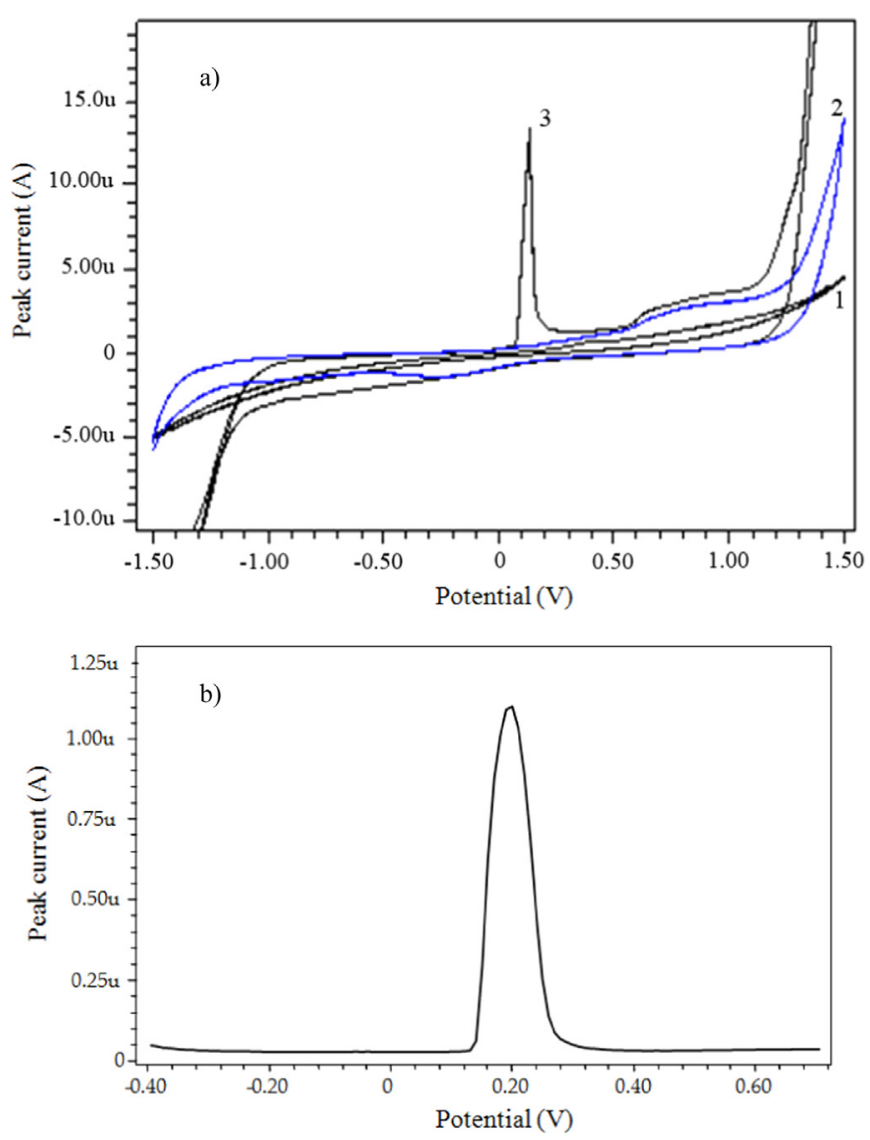

Fig. 2. (a) Cyclic voltammograms in $0.1 \mathrm{~mol} \mathrm{~L}^{-1}$ B.R. at $\mathrm{pH} 6$ between -1.5 and $1.5 \mathrm{~V}$, scan rate $100 \mathrm{mV} / \mathrm{s}$ : (1) CPE without 2-HBBH and $2 \mathrm{mg} \mathrm{L}^{-1} \mathrm{Ag}(\mathrm{I})$; (2) MCPE with 2-HBBH without $\mathrm{Ag}(\mathrm{I})$; and (3) $\mathrm{MCPE}$ with 2-HBBH and $2 \mathrm{mg} \mathrm{L}^{-1} \mathrm{Ag}(\mathrm{I})$. (b) Differential pulse voltammogram of $100 \mu \mathrm{g} \mathrm{L}{ }^{-1} \mathrm{Ag}(\mathrm{I})$ using a MCPE with 2-HBBH. Experimental conditions: $0.1 \mathrm{~mol} \mathrm{~L}^{-1}$ B.R. ( $\mathrm{pH} \mathrm{6}$ ); accumulation time $120 \mathrm{~s}$; reduction time $120 \mathrm{~s}$; reduction potential $-0.4 \mathrm{~V}$; pulse amplitude $50 \mathrm{mV}$; pulse time $40 \mathrm{~ms}$; potential step $4 \mathrm{mV}$ and time interval for potential step $0.1 \mathrm{~s}$.

peak appeared at approximately $252 \mathrm{~nm}$, which increased with the increase of $\mathrm{Ag}^{+}$ion concentration.

The continuous variation (Job's method) and the molar ratio method were applied to establish the stoichiometry of the complex formed during DPASV process. Visible spectrophotometry measurements of aqueous-ethanolic solutions of $\mathrm{Ag}(\mathrm{I})$ chelate buffered at pH 5.5 using $0.1 \mathrm{~mol} \mathrm{~L}^{-1} \mathrm{~K}_{2} \mathrm{HPO}_{4} / \mathrm{NaOH}$ were made at $252 \mathrm{~nm}$. The plots of absorbance suggested a complex formation with a 1:2 metal-ligand stoichiometry. The formation constant for the complex was evaluated to be around $10^{8} \mathrm{~mol}^{-2} \mathrm{~L}^{2}$ showing a very stable complex.

To optimize the performance of the 2-HBBH chemically modified carbon paste electrode for the electrochemical determination of silver in aqueous solution, the influence of parameters of DPASV on the response of $\mathrm{Ag}(\mathrm{I})$ were studied, including $\mathrm{pH}$, supporting electrolyte, accumulation and reduction time, reduction potential and carbon paste composition among other parameters.

\subsection{Effect of parameters}

\subsection{1. $\mathrm{pH}$ and supporting electrolyte}

The effect of $\mathrm{pH}$ on both the peak current and oxidation peak potential was evaluated. Due to the possible formation of sparingly soluble compounds on the electrode or of many soluble metallic compounds in the solution could deteriorate the stripping voltammetric signal because of the presence of high concentrations of inorganic or organic anions, the influence of the supporting

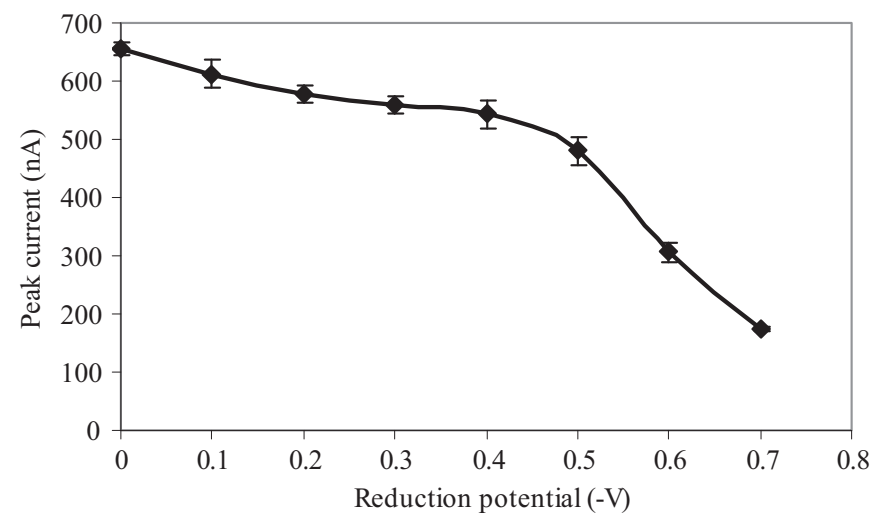

Fig. 3. Influence of reduction potential on the peak current. Experimental conditions: $100 \mu \mathrm{g} \mathrm{L}^{-1}$ of $\mathrm{Ag}(\mathrm{I}) ; 0.1 \mathrm{~mol} \mathrm{~L}^{-1} \mathrm{KH}_{2} \mathrm{PO}_{4} / \mathrm{NaOH}$ ( $\mathrm{pH} 5.5$ ); accumulation time $60 \mathrm{~s}$; reduction time $60 \mathrm{~s}$; purge time $60 \mathrm{~s}$; pulse amplitude $50 \mathrm{mV}$; pulse time $40 \mathrm{~ms}$; potential step $8 \mathrm{mV}$ and time interval for potential step $0.1 \mathrm{~s}$.

electrolyte was also tested. The $\mathrm{pH}$ was changed in the range from 2 to 10 and various buffer solutions (Britton-Robinson, Hydrion, Hepes, $\mathrm{NH}_{4} \mathrm{Cl} / \mathrm{NH}_{3}, \mathrm{~K}_{2} \mathrm{HPO}_{4} / \mathrm{NaOH}$ and $\mathrm{AcH} / \mathrm{NaAc}$ ) were evaluated. The sample solution $(20 \mathrm{~mL})$ containing $0.37 \mathrm{M}$ Britton-Robinson buffer, $0.25 \mathrm{M}$ HEPES, $0.25 \mathrm{M} \mathrm{NH}_{4} \mathrm{Cl} / \mathrm{NH}_{3}, 0.25 \mathrm{M} \mathrm{K}_{2} \mathrm{HPO}_{4} / \mathrm{NaOH}$ or $0.36 \mathrm{M} \mathrm{AcH} / \mathrm{NaAc}$, were pipetted into the voltammetric cell. The best response for both studies was obtained with $\mathrm{K}_{2} \mathrm{HPO}_{4} / \mathrm{NaOH}$ electrolyte solution at slightly acid $\mathrm{pH}$ values. Thus, a $\mathrm{pH}$ value of 5.5 was selected for further optimization studies. To complete the results, the influence of phosphate buffer concentration was also evaluated being $0.1 \mathrm{~mol} \mathrm{~L}^{-1}$ the optimum value chosen for the following experiments.

\subsubsection{Reduction potential}

The effect of the reduction potential on the stripping peak current of $100 \mu \mathrm{g} \mathrm{L}^{-1} \mathrm{Ag}(\mathrm{I})$ was studied by varying the reduction potential from 0 to $-0.7 \mathrm{~V}$. As it can be seen in Fig. 3, peak current shows a slight decrease from $0 \mathrm{~V}$ to $-0.5 \mathrm{~V}$. Further increase in the reduction potential led to a sharply drop reaching its lowest point at $-0.7 \mathrm{~V}$. Hence, a reduction potential of $0 \mathrm{~V}$ was used in all subsequent experiments. Several studies were also developed to achieve the optimum reduction potential for speciation studies with colloidal silver. As far as these samples were concerned, $-0.4 \mathrm{~V}$ was used as the optimum reduction potential.

\subsubsection{Scan rate and pulse amplitude}

The influence of scan rate was studied with $100 \mu \mathrm{g} \mathrm{L}^{-1}$ of $\mathrm{Ag}(\mathrm{I})$. This variable can be evaluated by both electrochemical parameters potential step or time interval for potential step. Potential step was selected in our studies varying from 2 to $12 \mathrm{mV}$ (20 to $120 \mathrm{mV} \mathrm{s}^{-1}$ scan rate, respectively) using a fixed time interval for potential step of $0.1 \mathrm{~s}$. The oxidation peak was found to vary linearly with the scan rate ranging from 20 to $120 \mathrm{mV} \mathrm{s}^{-1}$ (Fig. 4a). However, the shape of stripping peak became apparently asymmetry when scan rate was larger than $100 \mathrm{mV} \mathrm{s}^{-1}$ (potential step: $10 \mathrm{mV}$ ). For that reason, $100 \mathrm{mV} \mathrm{s}^{-1}$ was chosen as the scan rate for the following experiments.

The influence of pulse amplitude on the electrochemical response of $100 \mu \mathrm{g} \mathrm{L}^{-1} \mathrm{Ag}(\mathrm{I})$ was also investigated. Fig. 4b showed that the stripping peak current increased gradually with increasing differential pulse amplitude from 10 to $100 \mathrm{mV}$, which was the maximum equipment value. Thus, $100 \mathrm{mV}$ was selected as the differential pulse amplitude of the proposed method.

\subsubsection{Equilibration time and stirring speed}

Equilibration time and stirring speed were also evaluated. Equilibration time was ranged from 5 to $30 \mathrm{~s}$, and stirring speed 

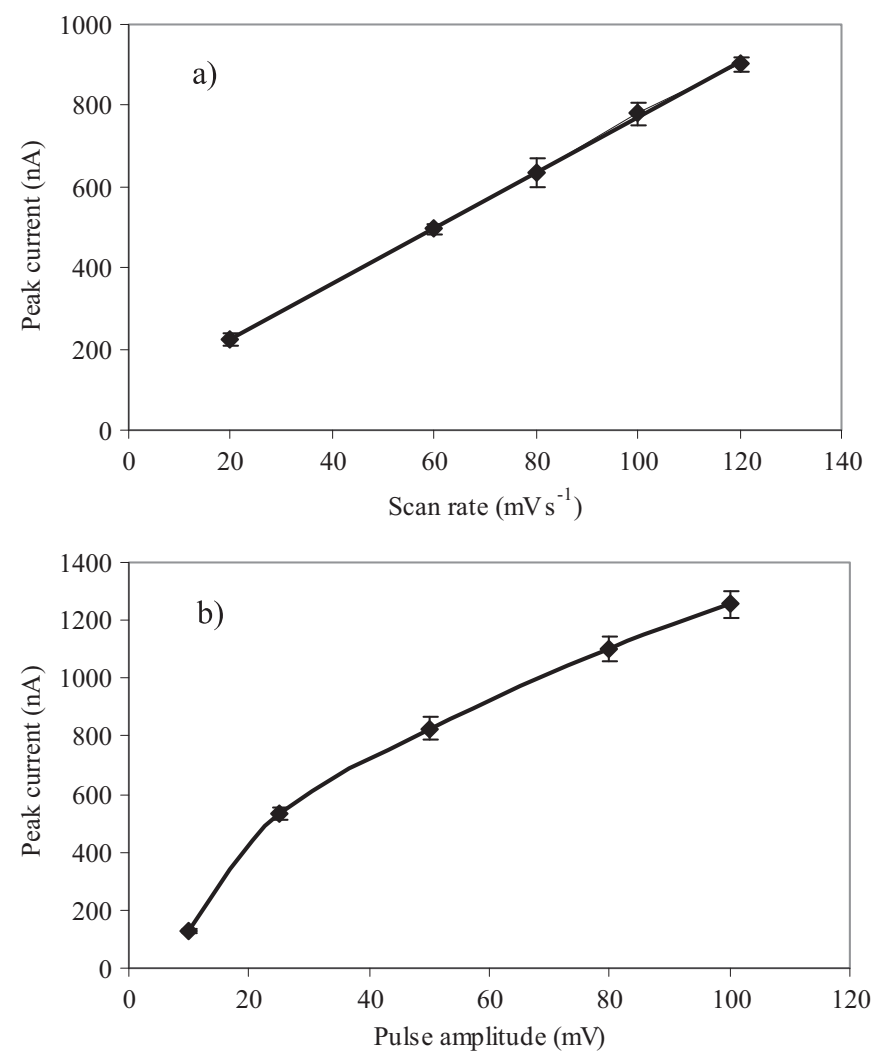

Fig. 4. Influence of (a) scan rate and (b) pulse amplitude on the peak current for $100 \mu \mathrm{g} \mathrm{L}^{-1}$ of $\mathrm{Ag}(\mathrm{I})$. Experimental conditions: $0.1 \mathrm{~mol} \mathrm{~L}^{-1} \mathrm{KH}_{2} \mathrm{PO}_{4} / \mathrm{NaOH}$ ( $\mathrm{pH} 5.5$ ); accumulation time $60 \mathrm{~s}$; reduction time $60 \mathrm{~s}$; purge time $60 \mathrm{~s}$; reduction potential $0 \mathrm{~V}$; pulse time $40 \mathrm{~ms}$ and time interval for potential step $0.1 \mathrm{~s}$. (a) Pulse amplitude $50 \mathrm{mV}$ and (b) Potential step $10 \mathrm{mV}$.

was varied from 1000 to $3000 \mathrm{rpm}$. Anodic stripping peak current of silver remained almost constant with the variation of both parameters without showing significant effects. In order to avoid long analysis times and achieve good reproducibilities of the measurements, $5 \mathrm{~s}$ and $2000 \mathrm{rpm}$ were selected as equilibration time and stirring speed, respectively (Fig. 5).

\subsubsection{Accumulation time, reduction time and purge time}

The sensitivity of the stripping voltammetric measurements can be affected to longer accumulation times. The more metal accumulated on the electrode surface, the higher peak current is obtained. Therefore, accumulation time is a decisive factor for a stripping voltammetric method. The effect of the accumulation time on the peak current of $20 \mu \mathrm{g} \mathrm{L}^{-1} \mathrm{Ag}(\mathrm{I})$ was tested in the range from 30 to $900 \mathrm{~s}$. The results indicated that the quantity of $\mathrm{Ag}$ (I) accumulated at the surface of the electrode increased with increasing accumulation time in the range of 30-600 s. However, the peak current decreased beyond $600 \mathrm{~s}$, indicating the saturation of the electrode surface after this time interval [39]. Taking into account the results, an accumulation time of $180 \mathrm{~s}$ could be selected giving enough sensitivity to measure silver and avoiding long analysis times. For quantification of silver at low concentration ranges, $600 \mathrm{~s}$ was chosen as accumulation time to achieve better sensitivity. The effect of reduction time was also examined. The stripping peak for $20 \mu \mathrm{g} \mathrm{L}^{-1}$ of $\mathrm{Ag}(\mathrm{I})$ was investigated in the range from 30 to $600 \mathrm{~s}$. The stripping signal for $\mathrm{Ag}(\mathrm{I})$ increased almost linearly up to $420 \mathrm{~s}$ falling sharply after this value. Therefore, a reduction time of $180 \mathrm{~s}$ was chosen again as a compromise between sensitivity and not very long analysis times. As aforementioned, for quantification of silver at low concentration ranges and to achieve lower detection limits, $420 \mathrm{~s}$ was chosen as reduction
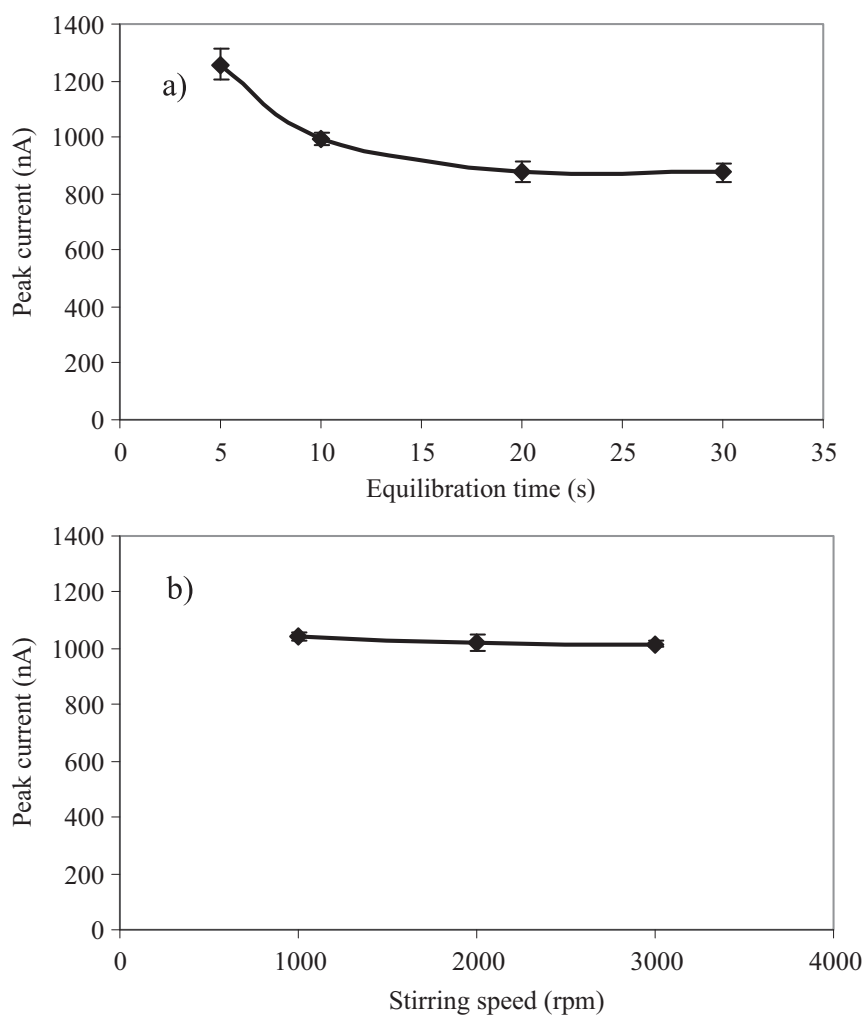

Fig. 5. Influence of (a) equilibration time and (b) stirring speed on the peak current for $100 \mu \mathrm{g} \mathrm{L}^{-1}$ of $\mathrm{Ag}(\mathrm{I})$. Experimental conditions: $0.1 \mathrm{~mol} \mathrm{~L}^{-1} \mathrm{KH}_{2} \mathrm{PO}_{4} / \mathrm{NaOH}(\mathrm{pH}$ 5.5); accumulation time $60 \mathrm{~s}$; reduction time $60 \mathrm{~s}$; purge time $60 \mathrm{~s}$; reduction potential $0 \mathrm{~V}$; pulse amplitude $100 \mathrm{mV}$; pulse time $40 \mathrm{~ms}$, potential step $10 \mathrm{mV}$ and time interval for potential step $0.1 \mathrm{~s}$.

time. To complete the optimization of the parameters related to time, purge time was also evaluated. Purge time was changed from 0 to $300 \mathrm{~s}$. Anodic stripping peak current of silver slightly increased up to $180 \mathrm{~s}$ and remained almost constant without showing significant effects after this value. Thus, $180 \mathrm{~s}$ was selected as purge time. Therefore, $180 \mathrm{~s}$ was selected for the three parameters evaluated.

In addition, the effect of stirring during reduction step was also investigated. A remarkable difference was obtained with and without agitation. Depending on the conditions, an increase of the stripping signal between 8.5 and 20 times was achieved (Table 2). Thus, the solution was stirred during reduction step for subsequent experiments.

\subsubsection{Effect of carbon paste composition}

Due to the accumulation of $\mathrm{Ag}(\mathrm{I})$ at the modified electrode was based on the complex formation between the metal ion and the modifier, the amount of 2-HBBH in the carbon paste composition could significantly affect the voltammetric response. Therefore,

Table 2

Effect of stirring during the reduction step on the peak current for $20 \mu \mathrm{g} \mathrm{L}^{-1}$ of Ag (I). Experimental conditions: $0.1 \mathrm{~mol} \mathrm{~L}^{-1} \mathrm{KH}_{2} \mathrm{PO}_{4} / \mathrm{NaOH}(\mathrm{pH} 5.5)$; purge time $60 \mathrm{~s}$; reduction potential $0 \mathrm{~V}$; pulse amplitude $100 \mathrm{mV}$; pulse time $40 \mathrm{~ms}$; potential step $10 \mathrm{mV}$ and time interval for potential step $0.1 \mathrm{~s}$.

\begin{tabular}{rlll}
\hline \multirow{2}{*}{ Accumulation time $(\mathrm{s})$} & Reduction time $(\mathrm{s})$ & \multicolumn{2}{c}{$I(\mathrm{nA})$} \\
\cline { 3 - 4 } & & Without stirring & With stirring \\
\hline 60 & 60 & 121.3 & 1947 \\
120 & 60 & 379.2 & 3237 \\
60 & 120 & 281.2 & 5637 \\
120 & 120 & 667.1 & 7195 \\
\hline
\end{tabular}




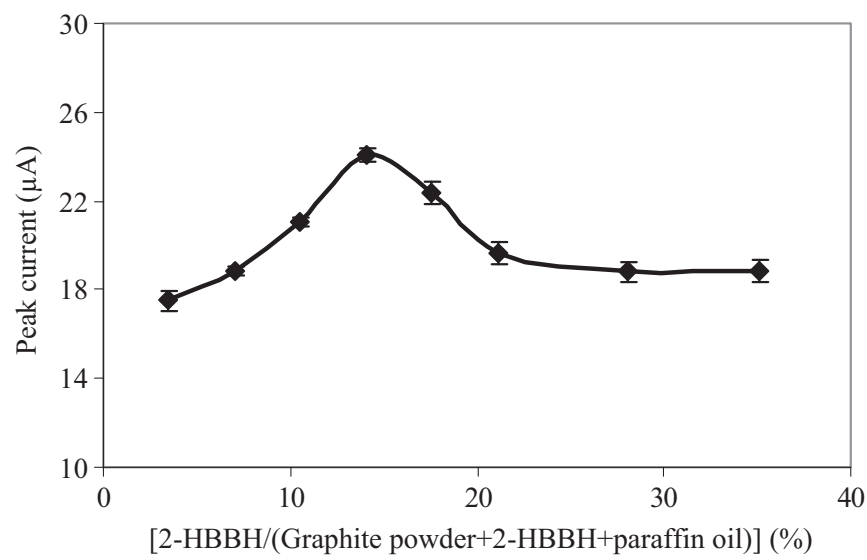

Fig. 6. Effect of modifier in the carbon paste composition. Experimental conditions: $100 \mu \mathrm{g} \mathrm{L}^{-1}$ of $\mathrm{Ag}(\mathrm{I}) ; 0.1 \mathrm{~mol} \mathrm{~L}^{-1} \mathrm{KH}_{2} \mathrm{PO}_{4} / \mathrm{NaOH}(\mathrm{pH} 5.5$ ); accumulation time $180 \mathrm{~s}$; reduction time $180 \mathrm{~s}$; purge time $180 \mathrm{~s}$; reduction potential $0 \mathrm{~V}$; pulse amplitude $100 \mathrm{mV}$; pulse time $40 \mathrm{~ms}$; potential step $10 \mathrm{mV}$ and time interval for potential step $0.1 \mathrm{~s}$. Stirring during reduction step.

electrodes with different percentages of modifier (from $3.5 \%$ to $35 \%$ ) and a fixed amount of paraffin at $29.7 \%$ were prepared. The experiments were performed with a $100 \mathrm{gg} \mathrm{L}^{-1} \mathrm{Ag}(\mathrm{I})$ solution for 3 min of accumulation time and 3 min of reduction time. Fig. 6 shows the effect of the ratio of 2-HBBH to the mixture of carbon paste on the peak current. It can be seen that the anodic peak current increased with increasing amount of modifier in the paste composition up to $14.1 \%$. The reason can be obviously attributed to the increase of accumulation sites. Higher modifier quantities in the paste composition showed a decrease in the peak current, probably related to a decrease of conductive area at the electrode surface $[30-32,40]$. According to these results a carbon paste composition of $14.1 \%(\mathrm{w} / \mathrm{w}) 2-\mathrm{HBBH}, 56.2 \%(\mathrm{w} / \mathrm{w})$ graphite powder and $29.7 \%(\mathrm{w} / \mathrm{w})$ paraffin oil was used in further experiments.

\subsubsection{Effect of acid $p H$ values and nature of the acid}

Due to a high concentration of chloride ions can be encountered in real water samples and the possibility of the formation of precipitates with the silver ions at slightly acid and basic $\mathrm{pH}$, several studies were carried out at lower $\mathrm{pH}$ values to avoid such interference. Different acids were studied (Table 3). The effect of the acid $\mathrm{pH}$ on the peak current of $100 \mu \mathrm{g} \mathrm{L}^{-1} \mathrm{Ag}(\mathrm{I})$ was tested in the range from 1 to 3 . Nitric acid was proposed as an alternative to the buffer solution to adjust the $\mathrm{pH}$ of the real water sample at $\mathrm{pH} 1$.

\subsection{Stability of the modified carbon paste}

Once optimum conditions were evaluated, practical usability of the developed MCPE was investigated by measuring the electrochemical signal of $\mathrm{Ag}(\mathrm{I})$ of several modified electrodes prepared

\section{Table 3}

Effect of acid pH values and nature of the acid on the peak current for $100 \mu \mathrm{g} \mathrm{L}^{-1}$ of $\mathrm{Ag}(\mathrm{I})$. Experimental conditions: accumulation time $180 \mathrm{~s}$; reduction time $180 \mathrm{~s}$; purge time $180 \mathrm{~s}$; reduction potential $0 \mathrm{~V}$; pulse amplitude $100 \mathrm{mV}$; pulse time $40 \mathrm{~ms}$; potential step $10 \mathrm{mV}$ and time interval for potential step $0.1 \mathrm{~s}$. Stirring during reduction step.

\begin{tabular}{lllll}
\hline $\mathrm{pH}$ & \multicolumn{5}{c}{$I(\mu \mathrm{A})$} \\
\cline { 2 - 5 } & $\mathrm{HNO}_{3}$ & $\mathrm{H}_{2} \mathrm{SO}_{4}$ & $\mathrm{HCl}$ & $\mathrm{K}_{2} \mathrm{HPO}_{4} / \mathrm{NaOH}$ \\
\hline 1 & 49.9 & 47.7 & 0.002 & - \\
2 & 41.9 & 41.1 & 5.4 & - \\
3 & 13.3 & 15.9 & 15.7 & - \\
5.5 & - & - & - & 1.2 \\
\hline
\end{tabular}

with the same composition (14.1\% of $2-\mathrm{HBBH}, 56.2 \%$ of graphite and $29.7 \%$ of paraffin oil) and each electrode was stored for different days. The experiments were performed with a $100 \mu \mathrm{g} \mathrm{L}^{-1}$ $\mathrm{Ag}(\mathrm{I})$ solution using a pH 1 adjusted with $\mathrm{HNO}_{3}, 3$ min of accumulation time and applying a reduction potential of $0 \mathrm{~V}$ for $3 \mathrm{~min}$. The stability of the modified carbon paste electrode was evaluated over a period of 2 months. During this period, 14 measurements were done (one measurement per day the first week and one per week after that). The peak current after this period of time was reproducible and no significant drift was observed $(50.6 \mu \mathrm{A} \pm 0.7 \mu \mathrm{A})$. The results obtained indicated the high stability of 2-HBBH in time. Therefore, the MCPE could be stored and be used after 2 months without any electrochemical signal loss.

\subsection{Analytical performance characteristics of the method}

To test the reproducibility of the method, 12 different electrodes were prepared in the same manner and they were evaluated by performing the determination of $100 \mu \mathrm{g} \mathrm{L}^{-1}$ of $\mathrm{Ag}(\mathrm{I})$ solution. The RSD obtained was $1.5 \%$ and the precision of the method was $0.95 \%$ at a significant level of $95 \%(n=12)$. These results indicated a very good reproducibility for $\mathrm{Ag}(\mathrm{I})$ detection with the developed electrode.

Under the optimum conditions, the peak current was found to increase linearly with the silver concentration over a wide range from 0.001 to $100 \mu \mathrm{g} \mathrm{L}^{-1}$ for $180 \mathrm{~s}$ accumulation time and $180 \mathrm{~s}$ reduction time. The correlation coefficient and equation of the linear regression were $R^{2}=0.999$ and $I_{\mathrm{p}}(\mu \mathrm{A})=(-0.21 \pm 0.19)+$ $(0.529 \pm 0.004) \mathrm{C}\left(\mu \mathrm{g} \mathrm{L}^{-1}\right)$ respectively, being the standard deviation of the regression of 0.49 . At higher silver concentrations than $100 \mu \mathrm{g} \mathrm{L}^{-1}$, the peak current decreased implying that the activity of the electrode can decrease due to the full coverage of the electrode. The detection limit, defined as $D L=3 S_{\mathrm{b}} / m$ [41], where $S_{\mathrm{b}}$ is the standard deviation of the blank $(n=5)$ and $m$ the slope of the calibration graph, was found to be $1.1 \mathrm{ng} \mathrm{L}^{-1}$ of $\mathrm{Ag}(\mathrm{I})$, which is far lower than the maximum contaminant level for total silver in drinking water fixed by the EPA guidelines. The quantification limit, defined as $Q L=10 S_{\mathrm{b}} / \mathrm{m}$ [41], was found to be $3.7 \mathrm{ng} \mathrm{L}^{-1}$ of $\mathrm{Ag}$ (I). To complete the methodology and its application to lower silver concentrations in natural water samples, the voltammetric signal was also studied in the range of $0.1-40 \mathrm{ng} \mathrm{L}^{-1}$, by increasing the accumulation time to $600 \mathrm{~s}$ and reduction time to $420 \mathrm{~s}$, showing a linear tendency in the whole range evaluated. The correlation coefficient and equation of the linear regression were $R^{2}=0.997$ and $I_{\mathrm{p}}(\mu \mathrm{A})=(0.03 \pm 0.07)+(0.105 \pm 0.003) \mathrm{C}\left(\mathrm{ng} \mathrm{L}^{-1}\right)$, respectively and the standard deviation of the regression was 0.11 . Using these conditions, detection and quantification limits were further improved up to $0.1 \mathrm{ng} \mathrm{L}^{-1}$ and $0.34 \mathrm{ng} \mathrm{L}^{-1}$, respectively.

These results have been compared with the analytical figures of merit of previous voltammetric procedures using other ligands as modifiers for the determination of silver (Table 4). It can be seen that this novel method using $2-\mathrm{HBBH}$ as a complexing ligand provides one of the lowest detection limits in comparison to the other techniques, and a wide linear range of application. The accumulation time is also favorable in this new methodology, requiring short values of this parameter to reach very low detection limits. To highlight a few, Dong and Wang [42] and Javanbakht et al. [32] reported methods for silver determination using DC18C6/Nafion and Tu-SBA-15, as the modifiers of the electrode, respectively, with favorable detection limits. However, the former was time-consuming and the latter had a linear calibration curve over a short range of $\mathrm{Ag}(\mathrm{I})$. Mohadesi et al. [31] prepared a MCPE modified with 3-amino-2-mercapto quinazolin-4(3H)-one. A detection limit of $0.4 \mu \mathrm{g} \mathrm{L}^{-1}$ and a long linear tendency from 0.9 to $300 \mu \mathrm{g} \mathrm{L}^{-1}$ of $\mathrm{Ag}(\mathrm{I})$ were obtained. However, $12 \mathrm{~min}$ of accumulation time was necessary to achieve such analytical 
Table 4

Comparison of analytical figures of merit of different voltammetric techniques for the determination of $\mathrm{Ag}(\mathrm{I})$.

\begin{tabular}{|c|c|c|c|c|c|}
\hline Electrode $^{\mathrm{a}}$ & Ligand $^{\mathrm{b}}$ & $\begin{array}{l}\text { Detection limit }\left(\mu \mathrm{g} \mathrm{L}^{-1}\right) \text { and accu- } \\
\text { mulation time }\end{array}$ & Linear dynamic range $\left(\mu \mathrm{g} \mathrm{L}^{-1}\right)$ & Application & Ref. \\
\hline MGCE & DC18C6/Nafion & $2 \cdot 10^{-4}(30 \mathrm{~min})$ & $2 \cdot 10^{-3}-1.1$ & Reagent-grade ammonium nitrate & [42] \\
\hline MCPE & Chelating resin & $0.03(5 \mathrm{~min})$ & $0.05-10.8$ & Waste water & [43] \\
\hline MCPE & $\begin{array}{l}\text { Tricresyl phosphate and } \\
\text { heptylsulfonate }\end{array}$ & $2.7 \cdot 10^{-4}(15 \mathrm{~min})$ & $0.03-0.14$ & Tap water & [44] \\
\hline MGE & DTT & 64.7 (5 min) & $64.7-259$ & Lake water and pond water & [45] \\
\hline MCPE & Alizarin violet & $0.01(3 \mathrm{~min})$ & $0.03-13$ & Waste water and zinc alloy samples & [30] \\
\hline MCPE & $\begin{array}{l}\text { 3-amino-2-mercapto quinazolin-4 } \\
\text { (3H)-one }\end{array}$ & $0.4(12 \mathrm{~min})$ & $0.9-300$ & $\begin{array}{l}\text { River water, tap water and X-ray } \\
\text { photographic films }\end{array}$ & [31] \\
\hline MPE & PTH & 60 (2 min $)$ & $70-1000$ & Waste water & [46] \\
\hline MCPE & Tu-SBA-15 & $5.4 \cdot 10^{-4}(5 \mathrm{~min})$ & $8.6 \cdot 10^{-4}-8.6 \cdot 10^{-3}$ & Seawater, tap water & [32] \\
\hline MCCE & PAR & $0.12(12 \mathrm{~min})$ & $0.5-300$ & $\begin{array}{l}\text { X-ray photographic films and super- } \\
\text { alloy samples }\end{array}$ & [47] \\
\hline MCPE & 2-HBBH & $\begin{array}{l}1 \cdot 10^{-3}(3 \mathrm{~min}) \\
1 \cdot 10^{-4}(10 \mathrm{~min})\end{array}$ & $\begin{array}{l}1 \cdot 10^{-3}-100(3 \mathrm{~min}) \\
1 \cdot 10^{-4}-0.04(10 \mathrm{~min})\end{array}$ & River water & This work \\
\hline
\end{tabular}

a MGCE: Modified glassy carbon electrode; MCPE: Modified carbon paste electrode; MGE: Modified gold electrode; MPE: Modified platinum electrode; MCCE: Modified carbon ceramic electrode.

${ }^{\mathrm{b}}$ DC18C6/Nafion: dicyclohexyl-18-crown-6 in Nafion-117.; DTT: DL-dithiothreitol; PTH: Polythiophene; Tu-SBA-15: Phenylthiourea-nanoporous silica gel; PAR: 4-(2pyridylazo)-resorcinol; 2-HBBH: 2-Hydroxybenzaldehyde benzoylhydrazone.

characteristics. More recently, Rohani et al. [47] developed a carbon ceramic electrode modified with 4-(2-pyridylazo)-resorcinol for silver ions analysis. The voltammetric response was linear from 0.5 to $300 \mu \mathrm{g} \mathrm{L}^{-1}$ and the detection limit was found to be $0.12 \mu$ $\mathrm{g} \mathrm{L}^{-1}$ of $\mathrm{Ag}(\mathrm{I})$. Nevertheless, the modified electrode developed by Rohani et al. was not applied to real water samples.

\subsection{Interference studies}

The influence of various possible interferents on the determination of $\operatorname{Ag}(\mathrm{I})$ was examined at a 100:1 interferent:analyte mass ratio using the optimized conditions. The results are presented in Table 5 . An error of $\pm 5 \%$ was considered tolerable. It was observed that $\mathrm{Zn}(\mathrm{II}), \mathrm{Cu}(\mathrm{II}), \mathrm{Pb}(\mathrm{II}), \mathrm{V}(\mathrm{V}), \mathrm{Tl}(\mathrm{I}), \mathrm{Mn}(\mathrm{II}), \mathrm{Ni}(\mathrm{II}), \mathrm{Cr}(\mathrm{VI}), \mathrm{Fe}(\mathrm{III}), \mathrm{Al}$ (III) and $\mathrm{Bi}(\mathrm{III})$ did not interfere even when present 100 times the concentration of $\operatorname{Ag}(\mathrm{I})$, showing recoveries between $96.5 \%$ and $104.5 \%$ and relative errors below $5 \%$. Slight interference was observed in the presence of $\mathrm{Co}(\mathrm{II}), \mathrm{Cd}(\mathrm{II})$ and $\mathrm{As}(\mathrm{V})$. The peak current was found to increase by 22.6, 24.1 and $21.0 \%$ when $\mathrm{Co}(\mathrm{II}), \mathrm{Cd}(\mathrm{II})$ and $\mathrm{As}(\mathrm{V})$ were present 100 times the concentration of $\mathrm{Ag}(\mathrm{I})$, respectively. The positive effect of these metals should be attributed to a catalytic effect or a possible formation of films in the electrode surface facilitating the accumulation of $\mathrm{Ag}(\mathrm{I})$ [48].

However, $\mathrm{Hg}$ (II) was found to reduce the peak current by $19.4 \%$

Table 5

Study of interferences by trace metals for the silver determination in solutions containing $0.1 \mathrm{mg} \mathrm{L}^{-1} \mathrm{Ag}(\mathrm{I})$ ion and $10 \mathrm{mg} \mathrm{L}^{-1}$ of interferent ions (100:1 interferent:analyte mass ratio).

\begin{tabular}{lcc}
\hline Interference & Recovery $(\%)$ & Relative error $(\%)$ \\
\hline $\mathrm{Tl}^{+}$ & 99.4 & -0.7 \\
$\mathrm{Mn}^{2+}$ & 98.4 & -1.6 \\
$\mathrm{Ni}^{2+}$ & 96.5 & -3.6 \\
$\mathrm{Cr}^{+6}$ & 103.1 & +3.0 \\
$\mathrm{Co}^{2+}$ & 129.3 & +22.6 \\
$\mathrm{Fe}^{3+}$ & 104.0 & +3.8 \\
$\mathrm{Zn}^{2+}$ & 100.6 & +0.6 \\
$\mathrm{Cd}^{2+}$ & 131.7 & +24.1 \\
$\mathrm{~V}^{5+}$ & 103.6 & +3.5 \\
$\mathrm{Al}^{3+}$ & 100.1 & +0.1 \\
$\mathrm{Bi}^{3+}$ & 100.8 & +0.8 \\
$\mathrm{Hg}^{2+}$ & 83.7 & -19.4 \\
$\mathrm{As}^{5+}$ & 126.6 & +21.0 \\
$\mathrm{Cu}^{2+}$ & 104.5 & +4.3 \\
$\mathrm{~Pb}^{2+}$ & 100.3 & +0.3 \\
\hline
\end{tabular}

at a 100 -fold mass concentration excess over $\mathrm{Ag}(\mathrm{I})$. In this case, the negative effect should be attributed to the complex formation of $\mathrm{Hg}$ (II) with the modifier preventing the accumulation of $\mathrm{Ag}(\mathrm{I})$ on the electrode. Peak potential for $\mathrm{Hg}$ (II) signal appears at $0.7 \mathrm{~V}$.

Nevertheless, the interferences found can not be considered of significant importance because the metals have been studied at higher concentrations than usually found in water samples.

Chloride ions were also evaluated due to the possible precipitation of $\mathrm{AgCl}$. The effect was studied by addition of different $\mathrm{NaCl}$ concentrations to a solution containing $10 \mathrm{ng} \mathrm{L}^{-1}$ of $\mathrm{Ag}$ (I) using the proposed method. It was observed a decrease of peak current when $\mathrm{NaCl}$ concentration was higher than $5 \mathrm{~g} \mathrm{~L}^{-1}$ of $\mathrm{NaCl}$ because of the lowering of free silver ions in solution. This must be taken into consideration when real water samples are analysed.

\subsection{Validation of the proposed method and real river water sample analysis}

Under the optimum conditions, the accuracy of the method was evaluated by the determination of $\mathrm{Ag}(\mathrm{I})$ in SLEW-3 estuarine water certified reference material (CRM). It is noteworthy to mention that dissolved $\mathrm{Ag}$ is not a certified concentration but rather an informational value in the reference material $\left(3 \mathrm{ng} \mathrm{L}^{-1}\right)$. Ndungu et al. [4] measured silver for SLEW-3 by ICP-MS, which compares well with the suggested informational value. Yang et al. also determined a close value for analysis of the same CRM using a similar flow injection method [49]. The results are described in Table 6. Due to the salinity of the SLEW-3 estuarine water was around $15 \mathrm{~g} \mathrm{~L}^{-1}$, a dilution of four times of the sample was required, giving a final salinity of $3.75 \mathrm{~g} \mathrm{~L}^{-1}$. As it can be observed, a very good agreement between the experimental and certified values for reference water with a relative error of $-1.3 \%$ was shown.

The method was also applied to the analysis of $\mathrm{Ag}(\mathrm{I})$ in three real river water samples collected from Guadalquivir river (southwest of Spain). Before use, the samples were filtered through a membrane of $0.45 \mu \mathrm{m}$ of diameter and digested with UV radiation. The salinity of the river samples was below $5 \mathrm{~g} \mathrm{~L}^{-1}$, then no dilution was required.

The results obtained by the proposed method (Table 6) were compared which those obtained by ICP-MS. The relative errors were $+3.4 \%$, $+1.5 \%$ and $-0.7 \%$, respectively, indicating the suitability of the proposed method for its use in natural water samples. 
Table 6

Determination of $\mathrm{Ag}(\mathrm{I})$ in estuarine water certified reference material (SLEW-3) and real river water samples (from Guadalquivir river, Spain) by the new proposed DPASV method $(n=2)$.

\begin{tabular}{lllll}
\hline Sample $^{\mathrm{a}}$ & $\begin{array}{l}\text { Salinity } \\
\left(\mathrm{g} \mathrm{L}^{-1}\right)\end{array}$ & \multicolumn{2}{l}{$\operatorname{Ag}(\mathrm{I})$ concentration $\left(\mathrm{ng} \mathrm{L}^{-1}\right)$} & $\begin{array}{l}\text { Relative error } \\
(\%)\end{array}$ \\
\cline { 3 - 4 } & & Expected & Found $^{\mathrm{b}}$ & \\
\hline $\begin{array}{l}\text { SLEW-3 } \\
\text { River water }\end{array}$ & $15^{\mathrm{c}}$ & $3^{\mathrm{d}}$ & $2.96 \pm 0.10$ & -1.3 \\
$\begin{array}{c}1 \\
\text { River water }\end{array}$ & 1.2 & $16.40^{\mathrm{e}}$ & $16.96 \pm 1.19$ & +3.4 \\
$\begin{array}{l}2 \\
\text { River water }\end{array}$ & 0.4 & $16.80^{\mathrm{e}}$ & $17.05 \pm 0.95$ & +1.5 \\
3 & & $47.50^{\mathrm{e}}$ & $47.16 \pm 0.41$ & -0.7 \\
\hline
\end{tabular}

a $600 \mathrm{~s}$ of accumulation time and $420 \mathrm{~s}$ of reduction time in diluted solution of $\mathrm{HNO}_{3}(\mathrm{pH} 1)$.

b $n=2$.

c The sample was 4 times diluted previous the analysis.

d Ascertained value.

e Determination by ICP-MS.

Table 7

Validation of the analysis of total silver, free silver ions and silver nanoparticles by the new proposed DPASV method.

\begin{tabular}{|c|c|c|c|c|}
\hline \multicolumn{2}{|c|}{ Sample ${ }^{\mathrm{a}}$} & \multirow{2}{*}{$\begin{array}{l}\begin{array}{l}\text { Determination by } \\
\text { ICP-MS }\end{array} \\
17.01 \pm 0.02^{\mathrm{b}}\end{array}$} & \multirow{2}{*}{$\begin{array}{l}\text { Determination by the } \\
\text { proposed method } \\
17.19 \pm 0.02^{c}\end{array}$} & \multirow{2}{*}{$\begin{array}{l}\begin{array}{l}\text { Relative error } \\
(\%)\end{array} \\
+1.1\end{array}$} \\
\hline M1 & $\begin{array}{l}\mathrm{Ag}_{\mathrm{T}} \\
\left(\mathrm{mg} \mathrm{L}^{-1}\right)\end{array}$ & & & \\
\hline & $\begin{array}{l}\mathrm{Ag}_{\mathrm{I}}(\mu \\
\left.\mathrm{g} \mathrm{L}^{-1}\right)\end{array}$ & $3.85 \pm 0.06$ & $3.94 \pm 0.02^{\mathrm{d}}$ & +2.3 \\
\hline & $\begin{array}{l}\mathrm{Ag}_{\mathrm{NP}} \\
\left(\mathrm{mg} \mathrm{L}^{-1}\right)\end{array}$ & $17.00 \pm 0.06$ & $17.19 \pm 0.03$ & +1.1 \\
\hline \multirow[t]{3}{*}{ M2 } & $\begin{array}{l}\mathrm{Ag}_{\mathrm{T}} \\
\left(\mathrm{mg} \mathrm{L}^{-1}\right)\end{array}$ & $18.64 \pm 0.07^{\mathrm{b}}$ & $18.13 \pm 0.05^{c}$ & -2.7 \\
\hline & $\begin{array}{l}\mathrm{Ag}_{\mathrm{I}}(\mu \\
\left.\mathrm{g} \mathrm{L}^{-1}\right)\end{array}$ & $66.64 \pm 1.20$ & $67.88 \pm 0.93^{e}$ & +1.9 \\
\hline & $\begin{array}{l}\mathrm{Ag}_{\mathrm{NP}} \\
\left(\mathrm{mg} \mathrm{L}^{-1}\right)\end{array}$ & $18.57 \pm 1.20$ & $18.06 \pm 0.93$ & -2.7 \\
\hline
\end{tabular}

$\mathrm{Ag}_{\mathrm{T}}$ : Total silver; $\mathrm{Ag}_{\mathrm{I}}$ : Free silver ions; $\mathrm{Ag}_{\mathrm{NP}}$ : Colloidal silver nanoparticles.

M1: dispersion of silver nanoparticles containing sodium citrate as stabilizer; M2: silver nanoparticles prepared in the laboratory by dissolving a specific amount of silver powder without stabilizer. Both aqueous solutions consisted on colloidal silver nanoparticles of $20 \mathrm{~nm}$ particle size. For speciation studies, samples were filtered through Nucleopore Track-Etch Membrane of $15 \mathrm{~nm}$ pore size filters.

a $180 \mathrm{~s}$ of accumulation time and $180 \mathrm{~s}$ of reduction time in diluted solution of $\mathrm{HNO}_{3}(\mathrm{pH}$ 1).

${ }^{\mathrm{b}}$ The sample was 10 times diluted previous the analysis.

c The sample was 200 times diluted previous the analysis.

d The sample was 10 times diluted previous the analysis.

e The sample was 20 times diluted previous the analysis.

\subsection{Validation of the proposed method to silver speciation}

As aforementioned, the increasing development of nanotechnology has evidently led to the emission of many different nanomaterials into the aquatic environment. On account of this, and their possibly toxic effects, the determination of silver nanoparticles in water samples can be considered of great interest in the aquatic field as well as the analysis of free silver ions. Under the optimum conditions, several studies were carried out to find the applicability of the developed MCPE in the determination of the different forms of silver. It was observed that both ionic silver and silver nanoparticles were accumulated on the electrode being determined by stripping voltammetry. Two aqueous solutions consisted on colloidal silver nanoparticles of $20 \mathrm{~nm}$ particle size were studied (Table 7). A small fraction of dissolved ionic silver can be found in the samples. In order to resolve the simultaneous presence of such forms of silver in the water samples, the proposed method was applied under the optimum conditions by using two steps. Firstly, total silver was directly determined by the proposed voltammetric method and then, the samples were filtered through $15 \mathrm{~nm}$ pore size filters to separate the colloidal silver nanoparticles and measuring the concentration of free silver ions in the solution. Silver nanoparticles were determined by subtracting the free silver ions measured after filtration from the total silver concentration calculated in the first step. For silver speciation, $-0.4 \mathrm{~V}$ was employed as reduction potential, increasing the peak current five times if compared with $0 \mathrm{~V}$ value when colloidal silver solution is measured. Different dilutions of the samples were required, giving final concentrations inside the linear calibration range. The data obtained by the proposed method were compared with those obtained by ICP-MS, showing good recoveries of free silver ions and silver nanoparticles with relative errors below $3 \%$, indicating the successful applicability of the proposed method to colloidal silver.

\section{Conclusion}

A selective and easy new procedure for the determination of silver in aqueous media using a modified carbon paste electrode (MCPE) by differential pulse anodic stripping voltammetry (DPASV) and 2-HBBH as the modifier ligand has been described. A Schiff base has been incorporated to the carbon paste electrode for the determination of silver in water samples in the field of voltammetry for the first time in this paper with excellent results. This method provides a low detection limit and a wide linear range of application. The highly sensitive response of $\mathrm{Ag}(\mathrm{I})$, simplicity, rapid response and its successful application in real water samples demonstrate that it is an adequate mercury-free alternative for the determination of this analyte in water. Moreover, ssatisfactory results were obtained for the speciation analysis of total silver, silver ions and silver nanoparticles.

\section{Acknowledgments}

The authors acknowledge the support of this research by Spanish Agency of International Cooperation: Program of Scientific Cooperation and Interuniversity Investigation (PCI-Mediterranean) (Projects: A/030523/10 and A1/041491/11).

\section{References}

[1] J.L. Barriada, A.D. Tappin, E. Hywel-Evans, E.P. Achterberg, Dissolved silver measurements in seawater, Trends Anal. Chem. 26 (2007) 809-817.

[2] A.D. Tappin, J.L. Barriada, C.B. Braungardt, E. Hywel-Evans, M.D. Patey, E. P. Achterberg, Dissolved silver in European estuarine and coastal waters, Water Res. 44 (2010) 4204-4216.

[3] S.N. Luoma, Y.B. Ho, G.W. Bryan, Fate, bioavailability and toxicity of silver in estuarine environments, Mar. Pollut. Bull. 31 (1995) 44-54.

[4] K. Ndungu, Dissolved silver in the Baltic Sea, Environ. Res. 111 (2011) 45-49.

[5] P.J. Doherty, D.F. Williams, in: H.G. Seiler, A. Sigel, H. Sigel (Eds.), Handbook on Metals in Clinical and Analytical Chemistry, Marcel Dekker, New York, 1994, pp. 563-569.

[6] J.J.Y. Peng, M.G. Botelho, J.P. Matinlinna, Silver compounds used in dentistry for caries management: a review, J. Dent. 40 (2012) 531-541.

[7] 〈http://www.atsdr.cdc.gov〉.

[8] D.C. Antonio, C. Cascio, Z. Jaksic, D. Jurasin, D.M. Lyons, A.J.A. Nogueira, F. Rossi, L. Calzolai, Assessing silver nanoparticles behaviour in artificial seawater by mean of AF4 and spICP-MS, Mar. Environ. Res. xxx (2015) 1-8.

[9] F. Piccinno, F. Gottschalk, S. Seeger, B. Nowack, Industrial production quantities and uses of ten engineered nanomaterials in Europe and the world, J. Nanopart. Res. 14 (2012) 1-11.

[10] M.I. Setyawati, X. Yuan, J. Xie, D.T. Leong, The influence of lysosomal stability of silver nanomaterials on their toxicity to human cells, Biomaterials 35 (2014) 6707-6715.

[11] M. Delay, T. Dolt, A. Woellhaf, R. Sembritzki, F.H. Frimmel, Interactions and 
stability of silver nanoparticles in the aqueous phase: influence of natural organic matter (NOM) and ionic strength, J. Chromatogr. A 1218 (2011) $4206-4212$.

[12] E. Navarro, F. Piccapietra, B. Wagner, F. Marconi, R. Kaegi, N. Odzak, L. Sigg, R. Behra, Toxicity of Silver Nanoparticles to Chlamydomonas reinhardtii, Environ. Sci. Technol. 42 (2008) 8959-8964.

[13] N. Silvestry-Rodriguez, E.E. Sicairos-Ruelas, C.P. Gerba, K.R. Bright, Silver as a disinfectant, in: G.W. Ware (Ed.), Reviews of Environmental Contamination and Toxicology, 191, Springer, USA, 2007, pp. 23-45.

[14] S.P. Pathak, K. Gopal, Evaluation of bactericidal efficacy of silver ions on Escherichia coli for drinking water disinfection, Environ. Sci. Pollut. Res. 19 (2012) 2285-2290.

[15] D.V. Quang, P.B. Sarawade, S.J. Jeon, S.H. Kim, J.K. Kim, Y.G. Chai, H.T. Kim, Effective water disinfection using silver nanoparticle containing silica beads, Appl. Surf. Sci. 266 (2013) 280-287.

[16] A. Sweeney, S.A. Sañudo-Wilhelmy, Dissolved metal contamination in the East River-Long Island sound system: potential biological effects, Mar. Pollut. Bull. 48 (2004) 663-670.

[17] National Primary Drinking Water Regulations: Final Rule, Environment Protection Agency, Washington DC, 1991 (Fed Reg 56:3526).

[18] T. Zhang, Y. Chai, R. Yuan, J. Guo, Potentiometric detection of silver (I) ion based on carbon paste electrode modified with diazo-thiophenol-functionalized nanoporous silica gel, Mater. Sci. Eng. C 32 (2012) 1179-1183.

[19] A. Sánchez, S. Morante-Zarcero, D. Pérez-Quintanilla, I. Sierra, I. Del-Hierro, Determination of $\mathrm{Hg}(\mathrm{II})$ in natural waters using a carbon paste electrode modified with hybrid mesostructured silica nanoparticles, Sens. Actuators B Chem 163 (2012) 38-43.

[20] A. Afkhami, T. Madrakian, S.J. Sabounchei, M. Rezaei, S. Samiee, M. Pourshahbaz, Construction of a modified carbon paste electrode for the highly selective simultaneous electrochemical determination of trace amounts of mercury(II) and cadmium(II), Sens. Actuators B - Chem 161 (2012) 542-548.

[21] P.H. Deng, Y.L. Feng, J.J. Fei, A new electrochemical method for the determination of trace molybdenum(VI) using carbon paste electrode modified with sodium dodecyl sulfate, J. Electroanal. Chem. 661 (2011) 367-373.

[22] Z. Gao, P. Li, Z. Zhao, Determination of iron(II) with chemically-modified carbon-paste electrodes, Talanta 38 (1991) 1177-1184.

[23] M.F. Mousavi, A. Rahmani, S.M. Golabi, M. Shamsipur, H. Sharghi, Differential pulse anodic stripping voltammetric determination of lead(II) with 1,4-bis (prop-2-enyloxy)-9,10-antraquinone modified carbon paste electrode, Talanta 55 (2001) 305-312.

[24] I. Svancara, K. Vytras, K. Kalcher, A. Walcarius, J. Wang, Carbon paste electrodes in facts, numbers, and notes: a review on the occasion of the 50-years jubilee of carbon paste in electrochemistry and electroanalysis, Rev. Electroanal. 21 (2009) 7-28.

[25] H. Ibrahim, Carbon paste electrode modified with silver thimerosal for the potentiometric flow injection analysis of silver(I), Anal. Chim. Acta 545 (2005) $158-165$.

[26] M.H. Mashhadizadeh, A. Mostafavi, H. Allah-Abadi, I. Sheikhshoai, New Schiff base modified carbon paste and coated wire PVC membrane electrode for silver ion, Sens. Actuators B - Chem. 113 (2006) 930-936.

[27] Q. Zhao, Y. Chai, R. Yuan, T. Zhang, C. Yang, A new silver(I)-selective electrode based on derivatized MWCNTs@SiO 2 nanocomposites as a neutral carrier, Mater. Sci. Eng. C 32 (2012) 1352-1357.

[28] A. Afkhami, A. Shirzadmehr, T. Madrakian, H. Bagheri, New nano-composite potentiometric sensor composed of graphene nanosheets/thionine/molecular wire for nanomolar detection of silver ion in various real samples, Talanta 131 (2015) 548-555.

[29] Ch. Labar, L. Lamberts, Anodic stripping voltammetry with carbon paste electrodes for rapid $\mathrm{Ag}(\mathrm{I})$ and $\mathrm{Cu}(\mathrm{II})$ determinations, Talanta 44 (1997) 733-742.

[30] Y.H. Li, H.Q. Xie, F.Q. Zhou, Alizarin violet modified carbon paste electrode for the determination of trace silver(I) by adsorptive voltammetry, Talanta 67
(2005) 28-33.

[31] A. Mohadesi, M.A. Taher, Stripping voltammetric determination of silver(I) at carbon paste electrode modified with 3-amino-2-mercapto quinazolin-4(3H)one, Talanta 71 (2007) 615-619.

[32] M. Javanbakht, F. Divsar, A. Badiei, F. Fatollahi, Y. Khaniani, M.R. Ganjali, P. Norouzi, M. Chaloosi, G.M. Ziarani, Determination of picomolar silver concentrations by differential pulse anodic stripping voltammetry at a carbon paste electrode modified with phenylthiourea-functionalized high ordered nanoporous silica gel, Electrochim. Acta 54 (2009) 5381-5386.

[33] Y. Yuan, Z. Cao, N. Fu, J. Wang, L. Weng, A. Bezerra-de-Carvalho, C. Peppe, Preparation, characterization, electrochemical studies and crystal structure determination of salicylaldehyde-aroylhydrazone, ferrocenyl-aroylhydrazone and salicylaldehyde-ferrocenoylhydrazone complexes of indium, J. Organomet. Chem. 637 (2001) 631-641.

[34] Y.H. Lu, Y.W. Lu, C.L. Wu, Q. Shao, X.L. Chen, R.N.B. Bimbong, UV-visible spectroscopic study of the salicyladehyde benzoylhydrazone and its cobalt complexes, Spectrochim. Acta A 65 (2006) 695-701.

[35] C. Mongay, V. Cerda, A Britton-Robinson Buffer of Known ionic strength, Ann. Chim. 64 (1974) 409-412.

[36] E. Espada-Bellido, M.D. Galindo-Riaño, A. Aouarram, M. García-Vargas, Applicability of 2-Hydroxybenzaldehyde Benzoylhydrazone in the determination of trace metals by adsorptive cathodic stripping voltammetry: relevancy of simultaneous determinations, Anal. Sci. 25 (2009) 903-909.

[37] M. Maczuga, A. Economou, A. Bobrowski, M.I. Prodromidis, Novel screenprinted antimony and tin voltammetric sensors for anodic stripping detection of $\mathrm{Pb}(\mathrm{II})$ and $\mathrm{Cd}(\mathrm{II})$, Electrochim. Acta 114 (2013) 758-765.

[38] H. Lin, M. Li, D. Mihailovic, Simultaneous determination of copper, lead, and cadmium ions at a $\mathrm{Mo}_{6} \mathrm{~S}_{9-x} \mathrm{I}_{x}$ nanowires modified glassy carbon electrode using differential pulse anodic stripping voltammetry, Electrochim. Acta 154 (2015) 184-189.

[39] B. Rezaei, M. Ghiaci, M.E. Sedaghat, A selective modified bentonite-porphyrin carbon paste electrode for determination of $\mathrm{Mn}$ (II) by using anodic stripping voltammetry, Sens. Actuators B - Chem. 131 (2008) 439-447.

[40] O. Estevez-Hernandez, I. Naranjo-Rodriguez, J.L. Hidalgo-Hidalgo de Cisneros, E. Reguera, Evaluation of carbon paste electrodes modified with 1-furoylthioureas for the analysis of cadmium by differential pulse anodic stripping voltammetry, Sens. Actuators B - Chem 123 (2007) 488-494.

[41] M. Valcárcel, Principios de Química Analítica, Springer, Barcelona (1999), p. 80

[42] S. Dong, Y. Wang, A Nafion/Crown ether film electrode and its application in the anodic stripping voltammetric determination of traces of silver, Anal. Chim. Acta 212 (1988) 341-347.

[43] P. Li, Z. Gao, Y. Xu, G. Wang, Z. Zhao, Determination of trace amounts of silver with a chemically modified carbon paste electrode, Anal. Chim. Acta 229 (1990) 213-219.

[44] I. Svancara, K. Kalcher, W. Diewald, K. Vytras, Voltammetric determination of silver at ultratrace levels using a carbon paste electrode with improved surface characteristics, Electroanalysis 8 (1996) 336-342.

[45] B. Zeng, X. Ding, D. Pan, F. Zhao, Accumulation and stripping behavior of silver ions at DL-dithiothreitol self-assembled monolayer modified gold electrodes, Talanta 59 (2003) 501-507.

[46] H. Zejli, J.L. Hidalgo-Hidalgo de Cisneros, I. Naranjo-Rodríguez, K. R. Temsamani, Stripping voltammetry of silver ions at polythiophene-modified platinum electrodes, Talanta 71 (2007) 1594-1598.

[47] T. Rohani, M.A. Taher, Preparation of a carbon ceramic electrode modified by 4-(2-pyridylazo)-resorcinol for determination of trace amounts of silver, Talanta 80 (2010) 1827-1831.

[48] G. Marino, M.F. Bergamini, M.F.S. Teixeira, E.T.G. Cavalheiro, Evaluation of a carbon paste electrode modified with organofunctionalized amorphous silica in the cadmium determination in a differential pulse anodic stripping voltammetric procedure, Talanta 59 (2003) 1021-1028.

[49] L. Yang, R.E. Sturgeon, On-line determination of silver in sea-water and marine sediment by inductively coupled plasma mass spectrometry, J. Anal. At. Spectrom. 17 (2002) 88-93. 